(2015) in Piazza, Roberta and Fasulo, Alessandra, eds. When identities are marked: Narrating lives between societal labels and individual biographies London: Palgrave.

\title{
The nice Stasi man drove his Trabi to the nudist beach:
}

\section{Contesting East German Identity}

It is only through memory that "the self of yesterday [is] connected to the self of today and of tomorrow" (Olzik et al 2011). Yet, while we as individuals might remember - as indeed we must, for in this lies the constitution of our very selves - it is society which influences what is memorable, and what should be cast out into the abyss of oblivion. This dynamic is perpetually renegotiated, as different versions of the past are called up in response to biographical life circumstances and the winds of historical change.

The study which I will describe in this chapter is an attempt to make sense of a small group of life stories as told to me twice, twenty years apart, in a context of acute political change. In 1992 I conducted interviews with 40 East Germans, most of whom were anti-state activists who had participated in significant ways in what has been called 'the bloodless revolution' of 1989. Twenty years later, in 2012, I conducted follow up interviews with 15 of the people with whom I had originally spoken. Although much has been written on the events of 1989, and the twentieth anniversary of those events was greeted with much media fanfare from around the world, there has in fact been very little investigation into the long-term experiences of those who have lived through these changes. That is 
precisely the focus of my own study, which combines a biographical and historical focus.

In the stories which they weave, individuals reveal how they position themselves within the communities that they live, to whom or what they see themselves as belonging to/alienated from, how they construct notions of power, and the processes by which such power is negotiated in the present moment and over time. For individuals, political narratives are the ligaments of identity, revealing how one constructs the boundaries of, and the connections between, the self and the social world.

One of the key questions raised by my project is how to frame 'the story of one's life' in the context of acute cultural and political transformation, and rupture. How one lives, and tells about one's life are after all questions about culture as much as of individual identity - if indeed there be such a thing. Mark Freeman uses the term "the space of selfhood" (2010:137) to refer to the interrelationship between culture, narrative and identity, and it is this complex space which forms the focus of my study.

The study which I began in 1992, two and a half years after the fall of the Berlin Wall and about 6 weeks after the opening of the files of the secret police, 'the Stasi', had as its original focus how political activists made sense of acute political change in which they themselves had been key actors. I conducted interviews with 40 East Germans, asking them to reflect on the political changes 
which had taken place in the previous few years. The people who participated in the research were, generally speaking, individuals who had participated in the citizens movements in the late 1980s; a subset of this group had been part of the critical opposition within the DDR for a much more substantial period of time. Two of the forty had been former employees of the Stasi. Thirty-three of the interviewees lived in Berlin, and seven were from Leipzig. Their ages spanned fifty years, from the early twenties to early 70s. Twenty-four were men, and 16 women. The topics ranged from ones relating to their own personal history to topics with broader significance, such as the meaning of Vergangenheitsbewaeltigung (that most particular of German terms, meaning 'working through the past'), the relationship between forgiveness and justice, and the importance of generational consciousness to realising social change. Twenty years after having conducted this initial study, I returned to East German and re-interviewed 15 of the original 40 participants. ${ }^{i}$ These follow-up interviews had a dual focus: how did the participants make sense of the changes which had happened in their own lives and in the country in the intervening two decades. In preparation for our conversations, I sent the interviewee a transcript and sound file of the original recording in 1992, and the interviews all began with questions asking participants to reflect on their experience of listening to their earlier selves. Some of the questions directly mirrored questions asked in 1992, and others were designed to elicit thoughts about new developments. While the original interviews had explored the concept of East German identity, that construction was in a far more nascent form than it is now, twenty years later. In this chapter, I will focusing on data which was collected twenty years after our initial interview. The cultural items which will form part of this 
discussion, specifically an Oscar-winning film and national museum, only came in to existence more than 15 years after the demise of East Germany.

\section{Marking East German Identity}

The fact that in the one and only democratic election in the existence of the German Democratic Republic, citizens voted to dissolve their country is the stuff of classic tragedy. The revolution eats its children, we are told, and so it happened in East Germany in 1989 (Andrews 2007:114)

For most of 40 years of the existence of the GDR, the outside world took little interest in what happened there. If someone from the west were asked to talk about their image of East Germans, if they had anything at all to say, it probably would have been with regards to the marked achievement of East German athletes, whose performance, they might insinuate, could have been enhanced by artificial means. All this changed very dramatically in the months leading up to and following the opening of the Berlin Wall on November $9^{\text {th }}, 1989$. Within six months, East Germans held their first democratic elections, in which they voted to dissolve their country. Less than one year after the opening of the wall came the reunification of Germany; both the scale and the urgency of these dramatic changes caught the public imagination of much of the world. Part of this attraction led researchers from around the globe to descend on what had once been East Germany to ask people about their lives, their sense of their new found freedom. As one observer remarked, in 1989 East Germans were the most interviewed people in the world. East Germans were constantly narrating their 
lives, both publicly and privately, and many encountered the documentation of their lives by others, in their Stasi files.

One question which I repeated in both 1992 and 2012 was In my research I have explored with respondents their sense of their East German identity. In both 1992 and 2012, I asked the same question: "If someone asked you where you were from, what would you say?" The responses I heard varied in scope, but almost everyone claimed for themselves an enduring sense of 'being from' a place which now was no longer.ii One of the greatest psychological challenges posed by the acute political change was that people had to effectively reconceptualise their relation to the state, not only in the present, but also recreate a viable past for themselves - one that was not necessarily false, but that was recast in light of those social positions and attachments which emerged as the most valued post 1989.

In a conversation with Andre Brie, a former leader in the communist party and one of its leading progressive theoreticians, I ask him about the role of East Germany in his own sense of identity. His answer is long and thoughtful.

A decisive one. I was marked by it, I was socialised and politicised over there. Many of my values come from East Germany. Things I hope I practice myself, e.g. modesty, living among people. I live in a village now, where hardly anyone has a proper job. Those are my friends, those are my neighbours. I work with them, and they help me. I'm pretty much the only one there who is from a somewhat higher social standing. I hope 
that's a positive aspect that comes from the GDR. At least, I want it to be that way, and I try to live that way.

But there are many other things, cultural things. Many GDR-writers, painters, musicians have influenced what kind of art is close to my heart. This opened my mind. ...Songwriters and singers from the GDR - that's something that I still value greatly today.

Another aspect is very important, as well. Maybe that only applies to someone who is left-wing, who thinks about alternative models of society. The GDR was not just a random concept, as there are so many in the political left. It was a powerful reality with its bad sides, with its failure, and possibly also with its positive aspirations. That is a huge treasure of experience I try to use. It's not like reading an essay, but it's having experienced something that did not work. ... We had 40 years of the GDR, that was our reality, that was our life. A huge compendium of mistakes from which the left-wing can learn. For me, the GDR is still very much alive, because I still deal with it.

Brie's comment here brings in many aspects of the enduring importance of his national identity, in its informal manifestations. It is ironic but not surprising that once the East German state was no longer, and its very explicit projects of national-identity- building thus extinct, there opened up a space for individuals to find their own sense of national identity. As Kelman (1997) has articulated, the relationship between personal and national identity is never straightforward, 
but rather is a lifelong negotiation between individuals and the societies in which they live. Although all states seek to impart a sense of belonging amongst their citizens, some of those efforts are more coercive than others. The attempts of the East German state were so pervasive across society that many citizens experienced national identity as something which was imposed upon them rather than a sense of identity with more organic roots. What many experienced after the demise of the state was effectively fertile ground for the germination of this sense of national belonging.

Thus it was that many people experienced the growth of a sense of their national identity at the very time that that nation was in the process of dissolving itself. East German author Christa Wolf (1997) describes "the manner and the speed with which everything connected with the GDR was liquidated, considered suspect" and, writing less than a decade after the 'wende'iii, still views herself and her fellow citizens as being "housed in a barracks under quarantine, infected with Stasi virus" (1997:241). This context makes ripe breeding ground for a siege mentality in which self-identification is primarily reactive, and in this case at least, retrospective - a recreating of a national sense of self in response to acutely changing conditions; anything associated with East Germany was regarded with disdain helped to create what Roßteutscher describes as a "counter-identity" (2000:74) iv. I am not anything so much as I am not East German.

Looking more closely at the extended excerpt from my interview with Andre Brie, it is clear that he has a very deep and continuing sense of belonging to East 
Germany. He was, he says, socialized and politicized 'over there.' The language here is telling. As we are speaking in the heart of Berlin, the use of the term 'over there' implies a distance that can only apply metaphorically. His entry into this discussion is via a sense of enduring values, as he describes the modesty which he hopes characterizes his village life and the relations with his neighbors. But his sense of being 'marked' by the legacy of East Germany is more than in the way he lives amongst his neighbours. Rather, it extends to the books he reads, the music he listens to, the art he admires; these he says, have 'opened my mind.' The use of this phrase here is intriguing. In what sense can artefacts of one's own culture be said to 'open one's mind'? To what? I think this sentiment can best be understood only in the context that they are remnants of a disappeared time. The third and final way in which Brie says that East Germany continues to play a significant role in his identity is in the sense of the model it represents - 'a reality ... a huge treasure of experience' which he contrasts with the abstract political attachments - theories - of some of his western colleagues. There is, he argues, still much to be processed from the 40 years of the GDR, and for him, these potential lessons mean that the GDR is ' still very much alive.'

Andre Brie embraces his East German identity, but it is a complex position which he occupies, particularly with regards to his affiliation with the Ministerium fur Staatsicherheit - the "MfS" or "Stasi" . The Stasi kept records on the lives of approximately one-quarter of the population of East Germany, monitoring virtually every aspect of society. They had approximately 125,000 full-time employees, and an additional 100,000 informants . Of the official, full-time employees, 1052 were "surveillance specialists" who tapped telephones, 2100 
steamed open letters, and 5000 followed suspects, thus earning their internal slogan "We are Everywhere."v. Although all of those who collaborated with the Stasi were strongly encouraged to come forward and to opening acknowledge their clandestine activities - and given strong incentives to do so - many chose to remain silent. The cost of owning up to espionage was potentially too great, and many who had spied on colleagues, neighbors, friends, and sometimes even family, hoped that they would not be found out. Andre Brie, like many East Germans, was an informal collaborator with the Stasi. Unlike many others, however, he chose to come clean about his actions, although it took him several years to do so. Shortly after our interview twenty years earlier, Brie explains to me, "I announced, driven by my own conscience, that I had been an unofficial collaborator of the Stasi. That was very difficult, because I didn't try to avoid the problems that arose... It's not pleasant, but until now, it gives me reason to think about myself and my politics in a critical and constructive manner... but for me, that was the right way. I can't do anything without starting with myself."

When I ask him why was it right to come clean about his involvements, he responds

Because I made those mistakes, not society. If I want to learn something, on both a personal and a political level, I must be consequent about this. It was a spontaneous decision, I could not reflect on it. Maybe it's just the way I was. Twenty years later, this proved to be right in a quite a fundamental way. It's one specific example of how you can deal with your 
personal responsibility in a very critical manner, with the whole GDR, and not deny yourself at the same time.

Brie is clear about the importance of acknowledging his connection to the Stasi, and believes that it is critical to do so both personally and politically.

As mentioned earlier, Brie describes the legacy of East Germany in his life as something which has 'marked' him. Looking at the whole of the passage in which he uses the term geprägt or 'marked' there is not evidence to suggest that he intends to indicate some form of stigmatization. Yet, as someone who collaborated with the Stasi, and who openly acknowledges doing so, one might guess that this aspect of his identity was one in which he was negatively labeled. But in his description of the effect of acknowledging his actions, the reverse seems to be the case. Ultimately this ownership of entanglements which clearly, and visibly, still make him uneasy, erases the necessity of 'denying himself'. Although there are a number of possible explanations for this, my own would be a combination of political and personal: 1) on the political front, although those who collaborated with the Stasi were looked down upon, the real disdain was reserved for those who did not come forward; and 2) in his personal life, the past twenty years have been a happy time for Brie, with a new a marriage and a young child. It might be argued that he can accept who he was at least partially because of who he is now.

Annette Simon, well-known psychoanalyst and daughter of East German writer Christa Wolf, uses language which is in some ways reminiscent of that employed by Brie. When I ask her "If someone asks you where you're from, what do you 
say?" she immediately responds "Ostdeutschland [East Germany]" and then laughs.

MA: What does that mean to you? Why do you say that?

AS: 20 years ago, I wouldn't have thought that I would emphasize that today. But now it really marks an identityvi. When a stranger asks me

so that it's clear from the start: I'm part of that. Then one can see, in what way exactly. It's a sign of identity, and it makes up more than half of my life. I want to show that.

In our conversation together, Simon makes the point that these days, perhaps more than in the past, it is important to make clear that East Germany is a very important part of one's biography - after all, "it makes up more than half of my life". At the time of our interview in 2012, she was in the process of preparing a keynote talk for a major international conference.

I say right at the beginning that I'm East German, because that tends to be forgotten by the Psychoanalytical Society. There have been several conferences on the history of German psychoanalysis, and East Germany just doesn't feature in that. So we have to make clear that we're there!

Again the claiming of an East German identity indicates a step towards affirming not only her own biography, but the very existence of the land of her birth, a movement to counter the tendency to forget. 
In this section I have discussed the ways in which two East Germans with very different biographies feel that their identity is 'marked' - that is to say, written on their very being. They have made concerted efforts to claim this identity, in all of its ambiguity, for themselves when they feel that it has been concealed - by themselves and/or by others. This open staking of a claim has been psychologically important and possibly liberating. Still, these negotiations over claims of national identity do not happen in a vacuum. Representing life under 40 years of state socialism in East Germany has been a recurrent focus of films, literature, and indeed museums.

\section{Pop Culture and the Representation of East German Life}

Over time, the creation and recreation of public narratives about East German identity would become a viable commodity, in terms of films, television, and even national museums. Some of these commodities were created by East Germans, but more often than not East German identity was being retrospectively narrated by those who were not East German. At the same time, there has sprung up amongst some East Germans what has been termed 'Ostalagie' a romantic remembering of a life which is no longer, which perhaps never was. Along with the historian Peter Burke, it is useful to ask here" who wants whom to remember what, and why? Whose version of the past is recorded and preserved' and equally 'who wants whom to forget what, and why'. As time passes, the story of East Germany appears to become more and more polished, but by whom? 
In my 20-year-follow-up interviews, I explored with respondents their feelings about the ways in which East German life had been popularly represented. The question which I posed specifically asked about their reactions to the movies The Lives of Others, Goodbye, Lenin!, and the German television series Wiessensee. I also asked them about their reactions to the DDR Museum, which opened in 2006. When they spoke about their reactions to these creations, they provided me with a wider context of how they felt their former country was being portrayed to an outside public. Their sense of their own East German identity was no doubt influenced by this larger context - as questions of identity always concern more than just the individual. As Annette Simon expresses above, acknowledging the role of East Germany in one's life is an antidote to the wider cultural tendency either to erase or forget it, or also as alternative, a counternarrative (Bamberg \& Andrews 2004), to the way in which it is portrayed, on the occasions when that happens.

A discussion of reactions to the film The Lives of Others (Das Leben der Anderen) is particularly telling. First, a word about the film, which came out in 2006, won the Academy Award for Best Foreign Language Film, and was nominated for Best Foreign Language Film at the $64^{\text {th }}$ Golden Globe Awards. The film cost $\$ 2$ million US dollars to make, and grossed more than \$77 million. - an international hit if ever there was one. The writer and producer was a 6'8" West German by the name of Florian Henckel von Donnersmarck, who lives in Los Angeles. When the film came out, many acquaintances said to me that this film gave them a sense of the issues which I had been exploring in my work. Each time I heard comments to this effect - and there were many - I cringed. In many ways, there is no doubt 
that the film was a great success the acting, the romantic plotline, the cinematography. I had no problem with any of these. In fact, the contrary could be said. My only problem with them was that they were so effective, and viewers became easily seduced in to thinking that what they were watching bore a resemblance to actual life in East Germany. It was, quite literally, a Hollywood version of a very painful moment in history. Was it created to be a factual representation of that past? No, it was created as a film, and judged as a film, most people agree that it deserved the acclaim it attracted. But as Timothy Garton Ash (2007) commented in his extensive piece on this film, it was 'very much intended for others. Like so much else made in Germany, it is designed to be exportable.' And this might be one of the main reasons why so many of my respondents took such offence to the way in which their country, their lives, their pain had been portrayed.

Perhaps the most common criticism of the film was that it presented life in East Germany as many wished it had been. As Konrad Weiss, himself a documentary filmmaker commented

KW: I think that's a nice fairy tale. Well done, a well-made film, with good actors. ...The story is well told, but it did not happen that way.

MA: What was not true in Life of Others?

KW: There never was a Stasi officer like the one they show in the film. Someone who really started to think about things and changed sides, in his mind at least. That did not happen.vii 
The term 'fairy tale' appears in several interviews, along with repeated mentions of Hollywood. What particularly offended the respondents was the inaccuracies of the movie, which they felt went beyond artistic license. Irene Kukutz published a piece on the movie which was titled "Kitsch on the Highest Level".

Annette Simon also published an article about the film, which she describes as 'a Western fairy-tale about the GDR - with tragic moments'. She suggests that perhaps not enough time has passed to be able to treat the subject matter less romantically. 'The problem is, that the portrayal of that era perhaps needs more time, I mean the GDR and the conflicts in the GDR, the representation. It's really difficult to translate this GDR-feeling artistically.' In juxtaposition to the fictional representations, Simon feels that 'The best things are documents, documentary films, reports, minutes from meetings - I get more use out of that.'

One might say that these criticisms are not fair - that the movie does not purport to be a documentary, and nor to represent the realities of East German state surveillance in all of its detail. But to do so would be to miss the point. Most respondents acknowledged that as a film, it worked. This was not the problem, or rather as Reinhard Weisshuhn states, its success was part of the problem, because many mistook the fiction for a representation of real life - their real life. In my interview with Ulrike Poppe, I ask her : '... for you who had so much direct experience of having the Stasi in your life, how did you feel watching this representation which made such a hit all over the world?' to which she responds 'I was annoyed, even though the acting is good. But the story isn't right.' A fictional story is one thing, but the story of her experience is quite another. This 
sentiment is echoed by others. For Poppe, perhaps the most grating aspects of the film was that those who made it simply had done sufficient research; several times she repeats to me how many 'mistakes' there were in the film. While acknowledging artistic license, nonetheless feels that

If one had informed oneself more, done better research. For example, it was not possible that one Stasi official had insight into all levels of a case: as an interrogator, as an observer, as someone who plans the procedure, as the person sitting there with his listening device, as someone who is directly in touch with the people. Different people were responsible for each of these levels. And because everyone only saw a small excerpt from the case, it wasn't possible that he could be swayed by getting to know this person. One should have done that differently. ... There are quite a few mistakes in the film.

Poppe, who was very familiar with the Stasi both as someone whose life was continually infiltrated by them, and more recently as one who works towards reintegrating them in to civil society, is particularly critical of the way in which they are portrayed in the film. Far from the lonely depiction in the film, she explains that

the Stasi were not people who didn't have family and friends, and all just lived on their own. The Stasi itself was one family, where they celebrated and drank and laughed time and time again, and made jokes. You didn't just command each other around. You can read about this, they [the film makers] could have informed themselves. That was the crucial thing: 
Your boss knew your family, your children, your wife. Your future wife was checked before marriage and if possible, won over to the Stasi as well. It was all very familiar, and that is what held, motivated and controlled people

She concludes by joking, "When I'm retired, I'll make a new movie!"

When I speak with Ruth Misselwitz, who had been the target of malevolent Stasi interference, she focuses on the portrayal of the kind, if conflicted, Stasi agent:

RM: This Stasi-man who listened to them in the attic, who [laughs] saves his victim's life - that is Hollywood... I never experienced anything like that. But that is probably the longing for reconciliation, for an end of the story, and that everything turns out well in the end.

To Ruth, the idea that a member of the Stasi would risk his own safety and save the life of the person he had been reporting was literally laughable. But as someone who has dedicated much of her personal and professional life to working on peaceful reconciliation, she suggests that the inclination to rewrite history in this way is evidence of the wish for a happy ending. Like Ruth, Werner Kratschell is a person of the church. He too sees the film as 'unrealistic. That is a Western dream. That is happy end. That is Hollywood. A man full of repentance, and so on. No!' Both Misselwitz and Kratschell challenge the construction of the restorative narrative which attracts so many. Writing about his work with Holocaust survivors, Geoffrey Hartman (1994) states “... we who were not there 
always look for something the survivors cannot offer us. ... it is our search for meaning which is disclosed, as if we had to be comforted for what they suffered.' Those who lived under the gaze of the Stasi for so many years do not draw comfort from its recent benign depiction in these cultural artefacts created by those who were not there and did not have to endure the impact of its intrusion in to their lives. It is not surprising why so many East Germans find this movie and the world which it portrays as an affront not only to history, but indeed to their own identity.

\section{Nudist beaches, spreewald pickles, and Trabis: The authentic East Germany}

The new DDR Museum, on the River Spree in the heart of Berlin purports to provide a more accurate representation of real life in the GDR. The museum was opened in the summer of 2006 - the same year that The Lives of Others was released - and already by 2008 it had been nominated for the European Museum of the Year Award. It is unusual in that the funds for its creation were entirely provided by a wealthy West German. It is, says Reinhard Weisshuhn, 'a commercial enterprise'. But what is its purpose? From its website, one learns that the museum:

is the only museum which concentrates on everyday life in the GDR. We don't only show the crimes of the State Security or the border defences at the Berlin Wall but we display the life of the people in the dictatorship: Maybe you know the spreewald pickles, nudism beaches and the Trabi the rest of the life in this socialist state is unfamiliar to most of the people in the world (http://www.ddr-museum.de/en/museum) 
Does this museum, then, represent a more realistic sense of daily life in the GDR? I was curious to know what my fifteen respondents made of this museum and of its representation of the lives they had lived.

It is telling that almost none of the fifteen project participants had actually been to the museumviii. Annette Simon says quite simply "It's not necessary for me" and then she laughs. Others were more elaborate in their responses, acknowledging that it is a successful tourist destination in Berlin, but does not serve to educate. Jens Reich explains:

it's some sort of fairy tale. Everything in this museum... You see the everyday things and gadgets and posters and slogans; you see the porcelain sets and all these things... I would not think that this ...can enlighten the young generation. They will simply look at it as something strange.

Reinhard Weisshuhn is one of the few participants who did in fact go to the museum. His description is immediate and direct:

MA: Have you ever been to the GDR museum? The new one? On the Spree? RW: Yes. It's for tourists.

MA: You're the first person we've interviewed who went there. What did you think about this representation of GDR life?

RW: Well, I don't know. I can't imagine that one really understand anything there. It's too funny, too touristy. Of course, one has to convey these messages with simple means, etc. But there, I have the feeling too 
much of the message is left out, and disappears behind the whole show

Ulrike Poppe offers a similar viewpoint. She describes the museum as "a legitimate, low-level attraction for tourists" and then adds "I regret that there's not another museum next door, showing everyday life and resistance in the GDR.”

Everyday life in East Germany is represented not in its complexity, but rather as kitschy pop-art. Everything East German appears very retro, strange and even funny. The everyday is transformed in to the exotic. On the museum's website, they claim: "There is much more to discover in the DDR Museum: watch TV in the authentic GDR living room" and then the lure: "Experience history in a vivid, interactive and playful way: The DDR Museum offers you a hands-on experience of the everyday life of a state long gone, the life in socialism." But those who lived through the years of state socialism might not find this approach to their history so very 'playful.'

The shop too is full of special objects from a bygone era: products to eat, smell and touch. Here one can purchase Spreewaldgurke, described as 'carefully selected gherkins from the Spreewald' with the signage 'Only Here.' And there are many books to buy, with titles such as Jeans in the GDR and Naturism in the $G D R$ with images of naked people adorning its cover; in these books one can learn about the natives who used to eat such strange gherkins, who mostly 
preferred to be naked but when they did wear jeans somehow couldn't get the right brand.

Visiting the museum, it is hard not to wonder for whom such a museum was created? One can easily understand why so many of the participants in my study had not been to the museum, and why those who had, stayed only very briefly. Here they are represented as a funny and slightly strange people, who lived in a bygone era. And it is in this context that one can more fully appreciate the determination of Annette Simon to introduce her prestigious presentation by positioning herself as an East German.

Clearly no one individual, nor even group, of East Germans can claim to represent all of East Germany. But in each of the examples here, those who have painted the image of East German were not only outsiders speaking to an audience of outsiders. Some say this is a natural extension of 'victor's justice' those who lose are not afforded the luxury of authoring their own lives. (What is undeniable, regardless of one's politics, is that projects such as Hollywood films and new museums, cost money, and here most East Germans still cannot compete with their Western counterparts. But these identity projects are also not really directed at East Germans. When Annette Simon says quite wryly "It's not necessary for me" she is saying that she already knows about what everyday life was like in East Germany. What is depicted in The Lives of Others and the DDR Museum might be about her - and her fellow citizens - but it is not really intended for her. As there is increasing currency (metaphorical and literal) in 
depicting East German life, more and more East Germans are engaging in a conscious attempt to offer an alternative narrative about East German identity

\section{The Enduring Legacy of East German Identity}

My project explores the meaning of East German identity East Germans, over time. How does one's sense of being from a particular country change, once that country is no longer? The case of East Germany is particularly intriguing, in that twenty years after unification both the chancellor and the president of Germany are East German. For some that might be read as an indicator of how successfully the unification has been. And yet the story for most of those with whom I spoke was more complicated than that. It is perhaps most useful here to separate national identity in to its formal (or official) and informal manifestations. The ground upon which official East German identity had been built was never very firm, and the more forcefully the state demanded public allegiance from, and control over the lives of, its citizens, the less they internalized a sense of belonging. Yet once the country had been dissolved, there opened a new space in which individuals began to feel more connection to their country which was then no longer. The fall of the wall opened up new spaces for East Germans to experience their common history, both that which they had lived through and that which they were making. Times of political upheaval are particularly ripe conditions for collective narrative reconstruction (Roßteutscher 2000:62) and this in turn has high potential for the renewal of collective identity. Thus it was that in my interviews, more than twenty years after the fall of the Berlin Wall, 
there lingered for all of my interviewees a very strong sense of themselves as being East German, not only in the past, but reconstituted in the present.

My follow-up interviews were guided by a seemingly simple question: I wanted my participants to tell me about how their lives had unfolded over the twenty years since we had last met. This involved not only taking stock of their personal lives - the emergence of new loved ones, the loss of others, the ability to travel, their professional development, their experience of aging, their relations to those who are both younger and older than them - but also placing these aspects of their lives in the wider political context of Germany as it has evolved post-1989. So what, after all, is the nature of this exercise? If remembering is a cultural practice, then how can I as a collector of stories account for what is being told to me? Here I have no choice but to take as my starting point that the context in which people are asked to account for their lives has everything to do with what they do and don't say, with what they perceive as tell-able, and that which might be secret, unknown or unknowable even to themselves. In Brockmeier's work on cultural memory, he refers to the 'cultural architecture of our knowledge' (2002:8). How is it that we know what we know? This is a question not only of epistemology and psychology, but also a question of politics and morality, demanding a close scrutiny of the dynamics of power and resistance in the ongoing negotiation of how we account for ourselves and the worlds we inhabit.

Those women and men who have spoken to me about their sense of national identity have done so in conversations with a lag time of twenty years, and this passage of time has implications for how and what they tell me. Gadamer argues 
that "objective knowledge can be arrived at only when there has been a certain historical distance" (1989/2011: 181) and that over time "new sources of understanding ... reveal unsuspected elements of meaning” (1989/2011:182). And yet, as Gadamer concedes, "the temporal dimension ... is not a closed dimension, but is itself undergoing constant movement and extension" (1989/2011:182). There is then, no 'perfect' place for standing back and trying to make sense of either the tumultuous political changes which surround us nor of the tugs and pulls of our personal lives, with the dreams and challenges which we face every day. How these same men and women will narrate their sense of national identity in twenty years' hence is an inviting question. The one thing we do know is that those constructions will themselves be influenced by the stories which are in wider circulation about the meaning of an identity which was forged in the long ago and faraway land of East Germany. 


\section{Bibliography}

Andrews, Molly (2003) “Continuity and discontinuity of East German identity following the fall of the Berlin Wall: A case study" in Gready, Paul, ed., Cultures of political transition: Memory, identity and voice London: Pluto Press.

Andrews, M. (1998) "One hundred miles of lives: The Stasi files as a people's history of East Germany" Oral History 26/1: 24-31.

Ash, Timothy Garton (2007) "The Stasi on Our Minds" The New York Review of Books http://www.nybooks.com/articles/archives/2007/may/31/thestasi-on-our-minds/?pagination=false [Accessed 4 February 2014]

Bamberg, Michale and Molly Andrews, eds. (2004) Considering Counternarratives: Narration and resistance Amsterdam: John Benjamins Publishing Company.

Brockmeier, Jens (2002) “Introduction: Searching for Cultural Memory” Culture and Psychology Vol 8(1): 5-14.

Freeman, Mark (2010). “The space of selfhood: Culture, narrative, identity”. In S.R. Kirschner \& J. Martin (Eds.), The Sociocultural Turn: The Contextual Emergence of Mind and Self New York: Columbia University Press

Gadamer, Hans-Georg (1989/2011) “Truth and Method” in Olick, Jeffrey, et al, eds. The Collective Memory Reader Oxford: Oxford University Press.

Hartman, Geoffrey, ed. (1994) Holocaust remembrance, the shapes of memory Oxford: Blackwell. 
Kelman, Herbert (1997) “Nationalism, Patriotism, and National Identity: SocialPsychological Dimensions" in Staub, Ervin and Bar Tal, Daniel, eds. Patriotism in the life of individuals and nations Chicago: Nelson Hall.

Olzik, Jeffrey, Vered Vinitzky-Seroussi, and Daniel Levy, eds. (2011) The Collective Memory Reader Oxford: Oxford University Press.

Roßteutscher, Sigrid (April 2000) “Competing narratives and the social construction of reality: The GDR in transition" German Politics Vol. 9. No. 1: 61-82.

Wolf, Christa (1997) Parting from Phantoms: Selected Writings, 1990-1994 Chicago: University of Chicago Press. 
i The number was limited to 15 primarily because of financial and logistical considerations. My decision of who to prioritise was based on a mixture of who I could locate, who was willing to participate, and who was still at least somewhat politically engaged (a criteria which also influenced whether or not I could find them.)

ii Of course we are all, in some sense, 'from' places which are no longer, as even when nations continue to exist, they do nonetheless change. Thus it is that people sometimes comment that they no longer recognize the country in which they grew up.

iii Wende, or turn, is the term which is widely used in Germany to refer to the events of 1989. However some East Germans find this term - and that of the closely-related wendehals, the turning of the neck - ideologically loaded and refrain from using it.

iv For more on the development and transformation of East German identity in the first decade after the fall of the wall, see Andrews 2003

v For a fuller account of this, see Andrews 1998.

vi The phrase Simon uses here is "jetzt markiert es wirklich eine Identität" indicating that for her, being East German is a defining feature of her identity.

vii. Only two of the fifteen respondents did not criticize the movie. Andre Brie felt that the film "showed a Stasi office from his human side, in his inner conflict. That was a real character like one always needs in art, no abstraction." As already mentioned, Brie was himself an informal informant for the Stasi. The other person who thought the film was realistic in its portrayal was Jens Reich, who in fact had Stasi employees living in his attic, concealed, just as it happened in the movie.

viii. It is interesting though not surprising that this museum was one of the very few which my daughter's class went to on their history fieldtrip to Berlin. 